\section{Management of San Jose Scale on Apple with Soybean-oil Dormant Sprays}

\author{
Raymond L. Hix ${ }^{1}$ and Charles D. Pless ${ }^{2}$ \\ Department of Entomology and Plant Pathology, The Universityof Tennessee, \\ Knoxville, TN 37901-1071
}

\author{
Dennis E. Deyton ${ }^{2,3}$ and Carl E. Sams ${ }^{2}$ \\ Department of Plant and Soil Sciences, The University of Tennessee, \\ Knoxville, TN 37901-1071
}

Additional index words. insecticide, petroleum oil, Quadraspidiotus perniciosus,

Malus $\times$ domestica

\begin{abstract}
The objective of this study was to examine efficacy of soybean oil dormant sprays to manage San Jose scale (Quadraspidiotus perniciosus Comstock) on apple (Malus $\times$ domestica Borkh.). On 14 Feb. 1994 and again on 20 Feb. 1995, 'Bounty' apple trees were: 1) left unsprayed (control) or sprayed to runoff with: 2) $3 \%(\mathrm{v} / \mathrm{v})$ or 3$) 6 \%$ degummed soybean oil with $0.6 \%$ (v/v) Latron B-1956 sticker spreader, or 4) 3\% 6E Volck Supreme Spray petroleum oil. Crawler emergence occurred 17 May-28 June, 7 July-30 Aug., and 7 Sept.-24 Oct. 1994. First-generation crawler emergence had started by 8 May in 1995. Both $3 \%$ petroleum oil and $6 \%$ soybean oil sprays reduced the numbers of first- and second-generation crawlers by $93 \%$ in 1994 and first-generation crawlers by $98 \%$ in 1995 . The 3\% soybean oil treatment reduced first- and second-generation crawlers by $60 \%$ in 1994 and first-generation crawlers by $83 \%$ in 1995 . In 1995, apple fruit infestations by first-generation scales on the $3 \%$ soybean-, $6 \%$ soybean-, and $3 \%$ petroleum oil-treated trees did not differ significantly, but all fruit were significantly less infested than the controls.
\end{abstract}

San Jose scale is a major pest of apple trees. It can injure fruit directly and can also reduce tree vigor by removing sap, eventually killing the tree. Introduced into the United States from China in $\approx 1870$ (Marlatt, 1902, 1906, 1953), this scale insect continues to be a major pest in apple-growing regions of North America (Jorgensen et al., 1981; McClain et al., 1990; Pfeiffer, 1985a, b; Reissig et al., 1985; Rice and Jones, 1988; Rice et al., 1979).

San Jose scale and several other insect pests usually are managed by dormant petroleum oil sprays. Butler et al. (1988) and Butler and Henneberry (1990) demonstrated that insect management on vegetables and field crops is plausible with soybean oil. Little work has been done with soybean oil on fruit crops, even though it is 1) a renewable agricultural

Received for publication 23 Feb. 1998. Accepted for publication 2 Sept. 1998. We thank the Tennessee Soybean Promotion Board for providing financial support for this study. Use of a company or product name does not imply approval or recommendation of the product to the exclusion of others that also may be suitable. The cost of publishing this paper was defrayed in part by the payment of page charges. Under postal regulations, this paper therefore must be hereby marked advertisement solely to indicate this fact.

${ }^{1}$ Graduate Student. Current address: Dept. of Entomology, Univ. of Arkansas, Fayetteville, AR 32702. ${ }^{2}$ Professor.

${ }^{3}$ To whom reprint requests should be mailed. product, 2) relatively nontoxic to humans, and 3) domestically abundant. Additionally, insect and mite pest species have not been reported to develop resistance to vegetable or petroleum oils (Chapman, 1967; Davidson et al., 1991; Hesler and Plapp, 1986; Johnson, 1980). Pless et al. (1995) reported that $2.5 \%$ and $5.0 \%$ soybean-oil dormant sprays resulted in $>95 \%$ San Jose scale mortality when evaluated within 2 weeks of treatment. Almost $100 \%$ control of San Jose scale was achieved when a second spray was applied.

Management of San Jose scale in Tennessee currently is accomplished using dormant and/or delayed-dormant petroleum-oil sprays. The objectives of this study were to: 1) determine the effect of a single dormant soybeanoil spray to manage San Jose scale on apple trees throughout the following growing season, and 2) study the life cycle of San Jose scale in eastern Tennessee.

\section{Materials and Methods}

'Bounty' apple trees that were $\approx 4 \mathrm{~m}$ tall, 4 $\mathrm{m}$ wide, and $3 \mathrm{~m}$ deep and heavily infested with San Jose scale were selected in a commercial orchard near Morristown, Tenn. The scale had killed several trees and caused extensive damage to fruit. Trees were: 1) left unsprayed (control) or sprayed on 14 Feb. 1994 and on 20 Feb. 1995 with: 2) $3.0 \%$ or 3) $6 \%(\mathrm{v} / \mathrm{v})$ degummed soybean oil, together with $0.6 \%$ (v/v) Latron B-1956 sticker spreader (Rohm and Haas Co., Philadelphia) or 4) $3.0 \%$
6E Volck Supreme Spray oil (Valent USA Corp., Walnut Creek, Calif.). An application of $0.6 \%$ Latron B-1956 was evaluated in preliminary experiments but had no significant effect, similar to the effect found for Latron AG44M on San Jose scale (Pless et al., 1995). The treatment units were single trees and the design was completely random with five trees per treatment. Sprays were applied to runoff at 0.4 MPa using a cart-mounted two-pump (electric) sprayer equipped with a handgun. One pump provided spray pressure to the handgun, and the other provided tank agitation.

Minimum and maximum temperatures for the $24 \mathrm{~h}$ after application ranged from 3.3 to $8.3^{\circ} \mathrm{C}$ in 1994 and from 7.2 to $13.9^{\circ} \mathrm{C}$ in 1995 . There was very little wind and no precipitation during treatment. The grower did not apply dormant sprays or other insecticides to the trees in 1994 or 1995, and no fungicides were applied in 1994. Fungicides applied by the grower in 1995 were as recommended in the Univ. of Tennessee Commercial Fruit Spray Schedule (Univ. of Tennessee, 1994).

Development of San Jose scale was related to degree-day (DD) accumulation using a physiological base temperature of $10.6^{\circ} \mathrm{C}$ (Baskerville and Emin, 1969; Howitt, 1993). The formula used for DD calculations for a single date was: $\mathrm{DD}=\left[\left(\right.\right.$ maximum ${ }^{\circ} \mathrm{C}+$ minimum $\left.\left.{ }^{\circ} \mathrm{C}\right) / 2\right]-10.6{ }^{\circ} \mathrm{C}$ (Howitt, 1993). Seasonal DD accumulation was started on 1 Mar. in both 1994 and 1995.

Shoots were collected from unsprayed trees on 14, 18, and 20 Feb. 1994 and again on 12 and 20 Feb. 1995 to determine the overwintering stage and survival rate of San Jose scale. Ten scales were removed from each of 10 shoots per tree to determine their stage of development and to assess viability.

Pheromone traps were used to monitor male scale emergence from 18 Feb. to 1 Nov. 1994 and from 24 Feb. to 1 July 1995. The traps were placed $2 \mathrm{~m}$ aboveground at three locations in the orchard. Trap liners were changed weekly and all male scales on the trap liners were counted. Pheromone obtained from Trece (Pherocon, Calif.) was added to the traps every 3 weeks.

Each tree was examined weekly for scale crawler activity between 17 May and 24 Oct. 1994 and between 8 May and 1 July 1995. Counts were initiated in the area of the tree with the highest activity, based on preliminary observations. Crawlers on the same area of the bark were then monitored and counted weekly for 3 min per tree using a $16 \times$ hand lens (Mague and Reissig, 1983).

Data were subjected to analysis of variance using SAS software (SAS Institute, Cary, N.C.). Separation of means was accomplished with Tukey's honestly significant difference test.

Because of poor fruit set in 1994, only 11 apples per treatment were sampled on 1 July for assessment of scale injury. Fruit were plentiful on all test trees in 1995; thus, 20 apples were selected randomly per tree on 13 June for evaluation of infestation by firstgeneration scale. Data from 1994 and 1995 were analyzed separately. 


\section{Results}

Of 1030 San Jose scale evaluated for winter survival on untreated trees in 1994, $81 \%$ were alive in the black-cap stage, $16 \%$ were dead, and $3 \%$ were adult females. Of the 733 scales evaluated for winter survival on untreated trees in $1995,82 \%$ were alive in the black-cap stage, $11 \%$ were dead, and $6 \%$ were adult females.

In 1994, the first flight of males began on DD 84, the second on DD 558, and the third on DD 1317 (Fig. 1). The flight periods occurred from 15 April-17 May, from 14 June-29 July, and from 1 Aug.-26 Sept. The first-generation crawler emergence began on DD 294, the second on DD 750, and the third on DD 1651. Emergence periods occurred from 17 April-1 June, 7 June-30 Aug., and 7 Sept.-24 Oct. In 1995, first-generation crawler emergence began on DD 286 and occurred from 8 May-20 June.

In 1994, treatments with $3 \%$ petroleum oil or $6 \%$ soybean oil reduced numbers of firstand second-generation crawlers $>93 \%$ (Fig. 2 ). Treatment with $3 \%$ soybean oil reduced first- and second-generation crawlers $>60 \%$. (Data were not collected on third-generation crawlers.) Differences between the effects of $3 \%$ petroleum oil and $6 \%$ soybean oil sprays on numbers of first- or second-generation crawlers in 1994 were nonsignificant. The 3\% petroleum-oil and 6\% soybean-oil sprays provided better control of San Jose scale than did 3\% soybean-oil spray during 1994.

In 1995, differences among treatments in reducing first-generation crawler populations were nonsignificant, but all treated trees had significantly fewer scales than did control trees (Fig. 3). First-generation scale populations were $83 \%, 98 \%$, and $98 \%$ lower on trees sprayed with $3 \%$ soybean oil, $6 \%$ soybean oil, and $3 \%$ petroleum oil, respectively, than on control trees.

In 1994, the numbers of scales per fruit were $25.7 \pm 5.6,0.5 \pm 0.2,0.1 \pm 0.1,0.1 \pm 0.1$ for unsprayed apple trees (controls), $3 \%$ soybean oil, $6 \%$ soybean oil, and $3 \%$ petroleum oil, respectively. A late freeze prevented adequate statistical analysis. In 1995, the numbers of first-generation scales per fruit were $139,3.1,1.2$, and 0.9 for the same treatments, respectively (Fig. 4). Infestations on the fruit following winter treatments were not significantly different among the three oils.

\section{Discussion}

Data in 1994 indicated that San Jose scale can have as many as three generations per year in Tennessee. McClain et al. (1990) reported four generations in North Carolina. In 1994 and 1995, scales in Tennessee overwintered predominantly in the black-cap stage, and $\approx 11 \%$ to $16 \%$ of overwintering scales died from unknown causes. The second-generation crawler emergence period was complete by 24 Aug. Since fruit harvest was complete by 30 Aug., most of the damage to fruit of this earlymaturing cultivar was caused by the first and second generations.

Prior to the beginning of this study, the test

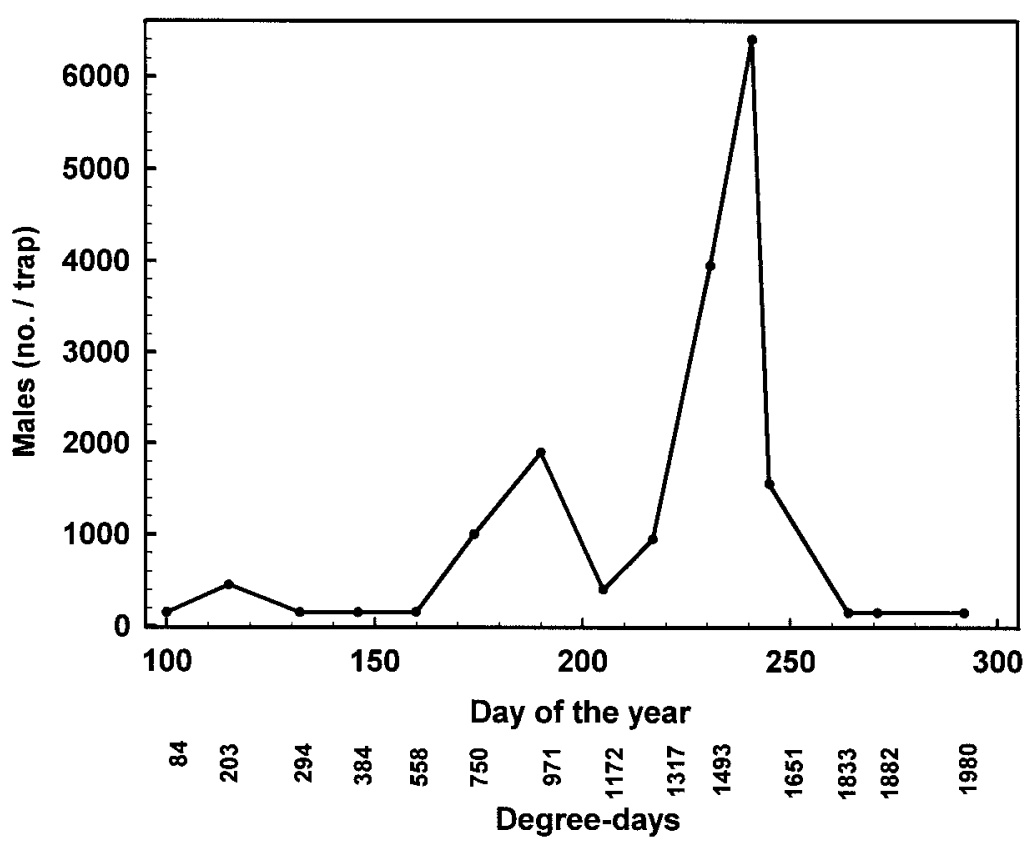

Fig. 1. Mean number of male San Jose scales collected in pheromone traps $(n=3)$ in 1994 from degree day (DD) 84 through DD 1980.

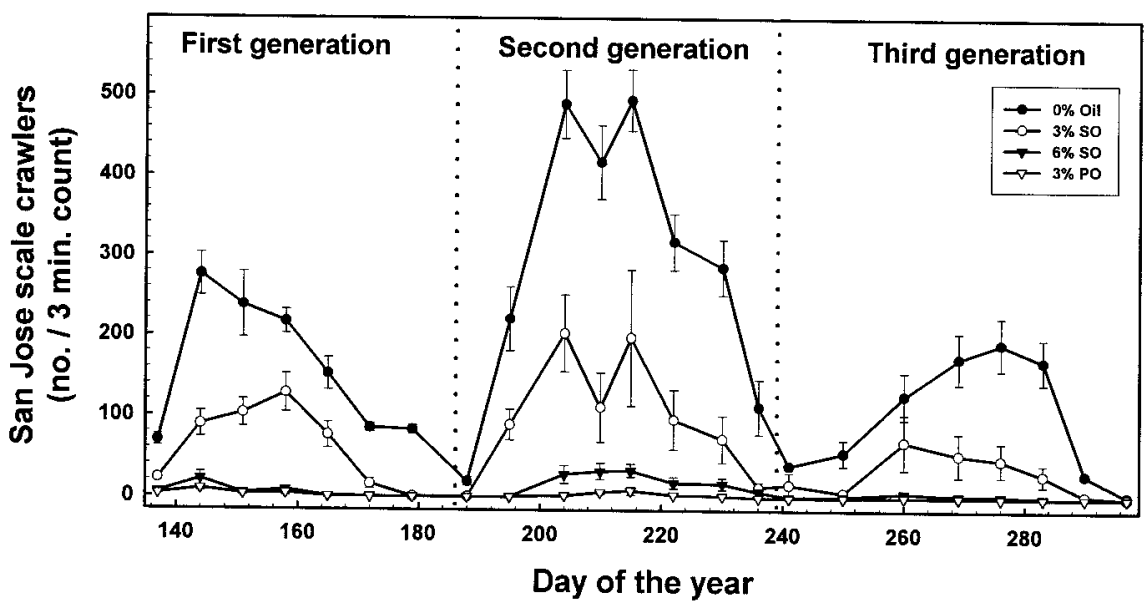

Fig. 2. Mean number of first-, second-, and third-generation San Jose scale crawlers per 3-min count in 1994 on apple trees sprayed on 14 Feb. with $3 \%$ or $6 \%$ soybean oil (SO), $3 \%$ petroleum oil (PO), or left unsprayed (control). Vertical bars \pm one standard error of the mean $(n=5)$.

trees were severely infested by San Jose scale. After 2 years of oil application, crawler abundance on all treated trees had been reduced dramatically compared with that on nontreated trees. The effects of $3 \%$ vs. $6 \%$ soybean-oil sprays on crawler populations differed in 1994 but were similar following the additional treatment in 1995 . One application of $3 \%$ soybean oil may not be sufficient enough to control the population, and therefore the treatment may have to be applied for two consecutive years. By Spring 1996, three of the five control trees were dead.

Natural enemies and substantially lower DD accumulation for September and October might account for the relatively low number of third-generation crawlers in 1994 (Fig. 2), allowing better management of first-generation crawlers on the 3\% soybean-oil treated trees in 1995 (Fig. 3). Aphytis proclia Walker
(Hymenoptera: Aphelinidae) was the most abundant parasitoid in the orchard (Hix, 1995). Adult activity occurred in August and September (Hix, 1995) and their numbers can increase rapidly. Small numbers of lady beetle (Coleoptera: Coccinellidae) larvae and adults and lacewing (Neuroptera: Chrysopidae) larvae were observed feeding on San Jose scale during the 1994 growing season. Larvae of both insects are voracious predators and could reduce scale populations substantially. In addition, DD accumulation decreased from $\mathrm{Au}-$ gust through September.

Dormant sprays of degummed soybean oil can be effective for the management of San Jose scale on apple trees. The $3 \%$ petroleum oil generally performed better than did the $3 \%$ soybean oil, perhaps because the soybean oil formulation did not appear to emulsify as well as the petroleum oil. Petroleum oil formula- 


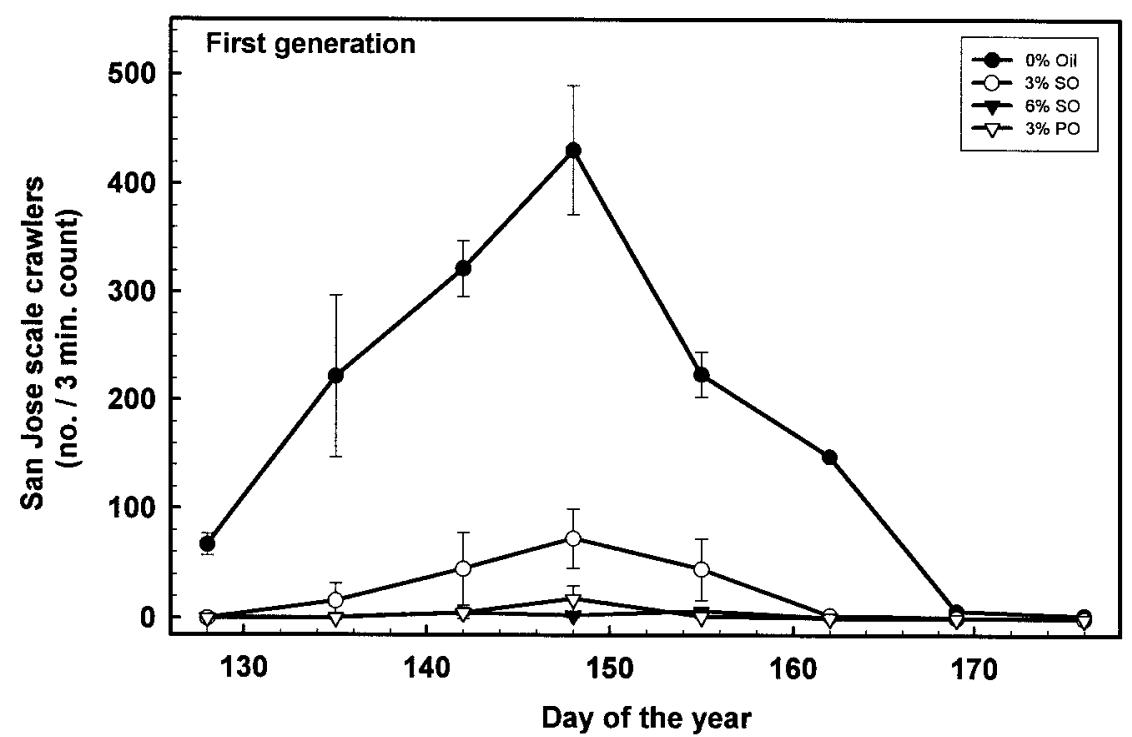

Fig. 3. Mean number of first-generation San Jose scale crawlers per 3-min count in 1995 on apple trees sprayed on $20 \mathrm{Feb}$. with $3 \%$ or $6 \%$ soybean oil (SO), $3 \%$ petroleum oil (PO), or left unsprayed (control). Vertical bars \pm one standard error of the mean $(n=5)$.

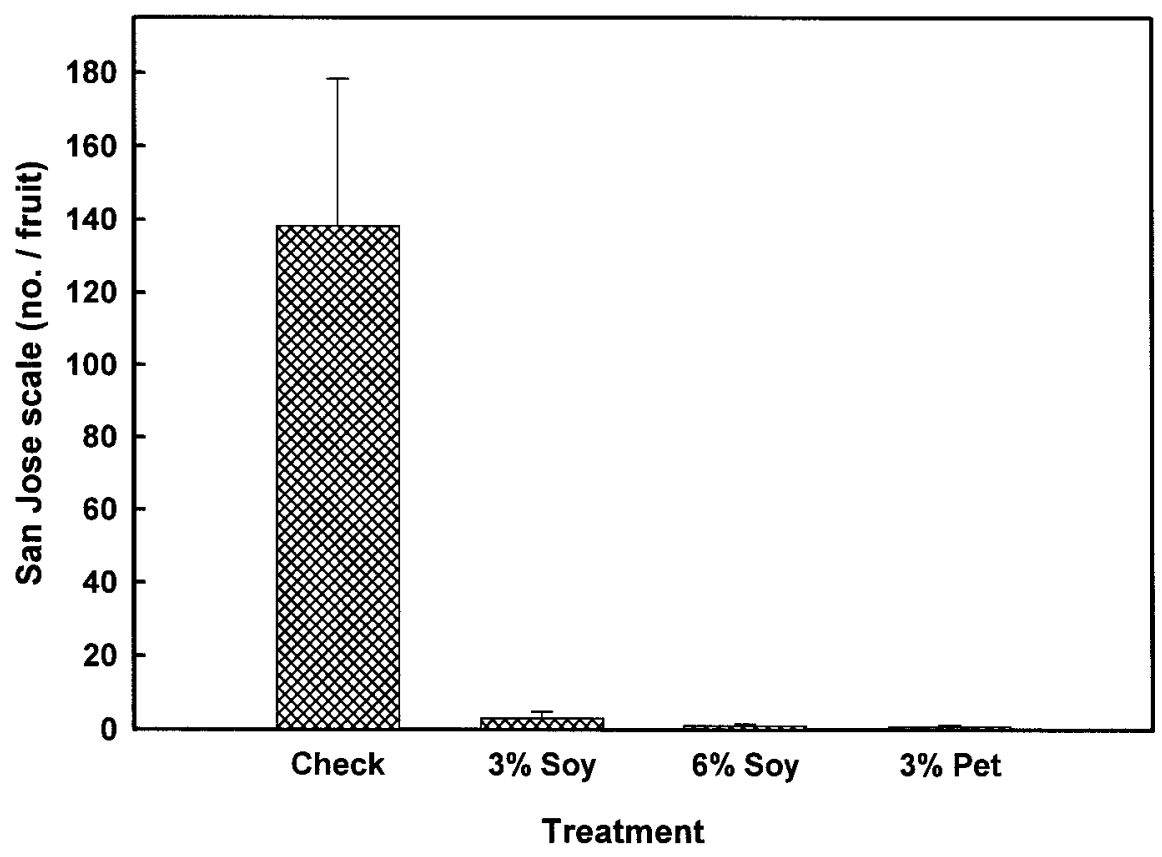

Fig. 4. Apple fruit infestation by first-generation San Jose scale on 13 June 1995. The trees were sprayed on 20 Feb. with $3 \%$ or $6 \%$ soybean oil (Soy), $3 \%$ petroleum oil (Pet), or left unsprayed (check or control). Vertical bars are one standard error of the mean $(n=100)$.

tions have been improved over the decades, but the insecticidal/miticidal properties of soybean oil have been studied only recently. In later trials, we found that Latron B-1956 emulsified soybean oil better if premixed with the oil prior to adding to the spray tank than if added separately. Soybean oil will perhaps be effective for management of many species of insects and mites (Bolles, 1995) on various deciduous fruit trees and other crops. Formulations with improved emulsification should improve its efficacy.

\section{Literature Cited}

Baskerville, G.L. and P.M. Emin. 1969. Rapid estimation of heat accumulation from maximum and minimum temperatures. Ecology 50:514 517.

Bolles, B. 1995. Management of European red mite populations on apple and plum trees with soybean oil. MS Thesis, Univ. of Tennessee, Knoxville.

Butler, G.D., D.L. Coudriet, and T.J. Henneberry. 1988. Toxicity and repellency of soybean and cottonseed oils to the sweetpotato whitefly and the cotton aphid on cotton in greenhouse studies. Southwest Entomol. 13:81-86.

Butler, G.D. and T.J. Henneberry. 1990. Pest control on vegetables and cotton with household cooking oils and liquid detergents. Southwest Entomol. 15:123-131.

Chapman, P.J. 1967. Petroleum oils for the control of orchard pests. New York State Agr. Expt. Sta. Bul. 814.

Davidson, N.A., J.E. Dibble, M.L. Flint, P.J. Marer, and A. Guye. 1991. Managing insects and mites with spray oils. Univ. California Div. of Agr. Nat. Res. Publ. 3347.

Hesler, L.S. and F.W. Plapp, Jr. 1986. Uses of oils in insect control. SouthwestEntomol. 11:(Suppl.)18.

Hix, R.L. 1995. Management of San Jose scale (Homoptera: Diaspididae) on apple trees with soybean oil dormant sprays and occurrence of San Jose scale parasitoids in eastern Tennessee. MS Thesis, Univ. of Tennessee, Knoxville.

Howitt, A.J. 1993. Common tree fruit pests. Michigan State Univ. Ext., NCR 63.

Johnson, W.T. 1980. Spray oils as insecticides. J. Arbor. 6:169-174.

Jorgensen, C.D., R.E. Rice, S.C. Hoyt, and P.H. Westigard. 1981. Phenology of the San Jose scale (Homoptera: Diaspididae). Can. Entomol. 113:149-159.

Mague, D.L. and H. Reissig. 1983. Phenology of the San Jose scale (Homoptera: Diaspididae) in New York State apple orchards. Can. Entomol. 115:717-722.

Marlatt, C.L. 1902. The San Jose scale: Its native home and natural enemy, p. 155-174. In: G.W. Hill (ed.). U.S. Dept. Agr. yearbook of agriculture. Govt. Printing Office, Washington, D.C.

Marlatt, C.L. 1906. The San Jose or Chinese scale. U.S. Dept. Agr. Bur. Entomol. Bul. 62:1-89.

Marlatt, C.L. 1953. An entomologist's quest. Monumental Printing Co., Baltimore.

McClain, D.C., G.C. Rock, and R.E. Stinner. 1990. San Jose scale (Homoptera: Diaspididae): Simulation of seasonal phenology in North Carolina orchards. Environ. Entomol. 19:916-925.

Pfeiffer, D.G. 1985a. Pheromone trapping of males and prediction of crawler emergence for San Jose scale (Homoptera: Diaspididae) in Virginia apple orchards. J. Entomol. Sci. 20:351-353.

Pfeiffer, D.G. 1985b. Toxicity of Avermectin B to San Jose scale (Homoptera: Diaspididae) crawlers, and effects on orchard mites by crawler sprays compared with full-season applications. J. Econ. Entomol. 78:1421-1424.

Pless, C.D., D.E. Deyton, and C.E. Sams. 1995. Control of San Jose scale, terrapin scale, and European red mite on dormant fruit trees with soybean oil. HortScience 30:94-97.

Reissig, W.H., R.W. Weires, D.W. Onstad, B.H. Stanley, and D.M. Stanley. 1985. Timing and effectiveness of insecticide treatments against the San Jose scale (Homoptera: Diaspididae). J. Econ. Entomol. 18:238-248.

Rice, R.E., S.C. Hoyt, and P.H. Westigard. 1979 Chemical control of male San Jose scale (Homoptera: Diaspididae) in apples, pears, and peaches. Can. Entomol. 111:827-831.

Rice, R.E. and R.A. Jones. 1988. Timing postbloom sprays for peach twig borer (Lepidoptera: Gelichiidae) and San Jose scale (Homoptera: Diaspididae). J. Econ. Entomol. 81:293-299.

University of Tennessee. 1994. Commercial fruit spray schedules. Univ. Tennessee Agr. Ext. Serv. Bul. PB1197. 